\title{
A nyílt hozzáférésü publikálás finanszírozási kérdései
}

\begin{abstract}
A tanulmány a nyílt hozzáférésü tudományos publikálás finanszírozási kérdéseivel foglalkozik. Arra összpontosít, hogyan érintik a kutatókat mint szerzőket a szakfolyóiratok által alkalmazott, szerzőoldali finanszírozást igénylő, nyílt hozzáférésü publikálás üzleti modelljei. A cikk egyrészt a vitatható tényezőkre és a problémákra kívánja felhívni a figyelmet, másrészt lehetséges megoldásokat és pozitív példákat szeretne bemutatni. Egyes tudományterületeken alacsony a finanszírozott kutatások aránya, így nehéz forrást szerezni a publikáláshoz. A kiadók és a tudományos társaságok egy része - bizonyos feltételek teljesülése mellett már talált megoldásokat a publikációs díj mérséklésére vagy elengedésére. A szakemberek egy köre amellett érvel, hogy a szakfolyóiratok elöfizetésére fordított összegeket át kell csoportosítani nyílt hozzáférésü publikálásra, problémát jelent azonban, hogy az előfizetések és a publikációs díjak forráshelyei nem feltétlenül azonosak. Mindez a közgazdaság- és gazdálkodástudomány müvelőit is érinti.* Journal of Economic Literature (JEL) kód: A13, I23, Z11.
\end{abstract}

A tudás közvetítésében, az új ismeretek és kutatási eredmények közlésében és terjesztésében meghatározó szerepet játszó tudományos publikálást az online környezet folyamatos változása és a kiadók új üzleti modelljeinek megjelenése kihívások elé állítja. Az egyik ehhez illeszkedő aktuális és releváns jelenség a közlemények nyílt hozzáférését (open access, OA) erősítö - a BOAI [2002] által elindított - törekvés, amely számos vitakérdést vetett fel a kutatók, a tudományszervezés és a tartalomszolgáltatás szakemberei között. Peter Suber definíciója alapján „[A] nyílt hozzáférésű (OA) irodalom digitális, online, ingyenes és a legtöbb szerzői jogtól és licenckorlátozástól mentes.” (Suber [2012] 4. o.) E tanulmány kizárólag a tudományos jellegü publikációk nyílt hozzáférésével foglalkozik, a szakfolyóiratokra, illetve az azokban megjelenő cikkekre koncentrálva.

* Jelen tudományos közleményt a szerző a Pécsi Tudományegyetem alapítása 650. évfordulója emlékének szenteli. A szerző ezúton mond köszönetet a lektoroknak kritikai megjegyzéseikért, valamint továbbgondolkodásra ösztönző észrevételeikért.

Kovács Kármen egyetemi docens, Pécsi Tudományegyetem Közgazdaságtudományi Kar Kvantitatív

Menedzsment Intézet (e-mail: karmen@ktk.pte.hu).

A kézirat első változata 2016. május 12-én érkezett szerkesztőségünkbe.

DOI: http://dx.doi.org/10.18414/KSZ.2017.2.185 
E téren a megoldatlan kérdések és a szakmai vita jelentős része gazdasági jellegü, elsősorban a finanszírozáshoz és az üzleti modellhez kapcsolódik.

A nyílt publikálás alapelve, hogy a közpénzből finanszírozott kutatások eredményeiből készülő publikációkat mindenki számára szabadon hozzáférhetővé kell tenni; a nyílt hozzáférés korlátozása gátolja a tudás- és ismeretanyag elterjedését és felhasználását, következésképpen fékezi az innovációt és a növekedést is (Finch [2012]). Az információknak és gondolatoknak a társadalmi értéke valójában annál inkább növekszik, minél több egyén számára válnak hozzáférhetővé, és minél többen tudják hasznosítani azokat (Houghton [2002]). Mayer [2013] a nyílt hozzáférés jelentőségét ahhoz az összefüggéshez köti, amely szerint a kutatásra fordított közberuházások megtérülése akkor éri el a maximumát, ha a közzétett tudás közjószággá válik. Mindez pedig összhangban áll az OECD [1997] azon megállapításával, hogy egy tudásgazdaság sikeressége legalább annyira múlik a rendszer tudáselosztásának hatékonyságán, mint tudástermelő képességén - így rendkívül nagy gazdasági jelentősége van a tudományos kommunikáció eredményességének.

Tanulmányunk célja azoknak a tényezőknek a feltárása, amelyek a szakfolyóiratok által alkalmazott nyílt hozzáférésü üzleti modelljeiben a kutatókat mint szerzőket érintik, különösen a szerzőoldali finanszírozást igénylő publikálás szempontjából. Nem a nyílt hozzáférésü publikálás ellen szólunk, annak számos előnye - különösen a tudományos eredmények széles körü és gyors terjedésének és nyílt hozzáférésének lehetősége elismerést érdemel. Sokkal inkább a szerzői oldalról szükséges finanszírozást magukban foglaló üzleti modellek vitatható elemeire és problémáira szeretnénk felhívni a figyelmet, ugyanakkor lehetséges megoldásokat és pozitív példákat is bemutatunk, minthogy mindez - a tudományterületre jellemző kutatási és publikálási szokásokból eredően különösen érinti a közgazdaság- és gazdálkodástudomány művelőit.

Elsőként a nyílt hozzáférésủ publikálás három fö formáját mutatjuk be. Majd a szerzőoldali finanszírozást igénylő üzleti modellek kritikus pontjait és megoldási lehetöségeit helyezzük a középpontba. Ennek során a nyílt hozzáférésű folyóiratok piacának és bevételének sajátosságait, a nem finanszírozott kutatások eredményeinek nyílt hozzáférésü közlési nehézségeit, az ilyen publikálás intézményi szintű finanszírozási érintettségét, valamint a kutatókat foglalkoztató intézmények szintjén az előfizetés és a nyílt publikálás viszonyát tárgyaljuk. Az írás a kérdéskör rendszerszintü megközelítéséhez füzött megjegyzésekkel zárul.

\section{A nyílt hozzáférésű publikálás típusai}

A nyílt hozzáférésű publikálásnak három nagy csoportja különböztethető meg: az arany, a zöld és a hibrid jellegü közzététel. A köztük lévő alapvető eltérés a finanszírozás formájában és a hozzáférés jellegében van. A finanszírozásra összpontosítva mutatjuk be öket.

1. Az arany közzététel olyan folyóiratban történik, amely cikkeit teljes szöveggel közvetlenül elérhetővé teszi kiadójának honlapján keresztül. A szerkesztőségi munka és a beküldött kéziratok gondozása ugyanolyan módon történik, mint a hagyományos folyóiratok 
esetében. Azilyen folyóiratokra jellemző internetalapú üzleti modell a cikkek tartalmához minden olvasó részére azonos és ingyenes, közvetlen hozzáférést biztosít. A cikkek szerzői számára viszont többnyire publikálási költségek merülnek fel, hacsak egy nonprofit szervezet által müködtetett folyóirat nem biztosít ingyenes közlést. Számos esetben azonban az elfogadott kéziratok publikálásáért a szerzői oldalról fizetni kell. A nyílt hozzáférés arany változata kapcsán a továbbiakban ez utóbbi típusra fordítjuk a figyelmet, mivel ez nagyon fontos kérdéseket vet fel a finanszírozáshoz kapcsolódóan.

A szerzői oldalról felmerülő költséget a leggyakrabban mint a cikkre vonatkozó eljárási díjat (article processing charge, APC) említik. Ezt azonban többnyire nem közvetlenül maga a szerzö fizeti, hanem foglalkoztató intézménye vagy a kutatását finanszírozó szervezet. Suber fel is hívja a figyelmet arra, hogy a nyílt hozzáférés arany verziójában nem helyes a „szerzői díj” fogalom használata; a „publikációs díj”, az „eljárási dij” vagy a „szerzőoldali díj” jobban kifejezi, hogy a közlés költségét nem feltétlenül a szerző fizeti (Suber [2012] 138. o.). Amint az eljárási díjat kifizetik, a befogadott tanulmány végleges verziója, vagyis a megjelenő cikk teljes terjedelmében azonnal online hozzáférhetővé válik. Ebben az esetben nem érvényesül tehát embargó, vagyis nincs késedelem a cikk lapban való megjelenése és nyílt hozzáférése között.

2. A zöld közzététel lényege, hogy a szerző elhelyezi, illetve saját maga archiválja tanulmányát szabad közfelhasználásra - az esetleges embargó lejárta után - egy intézményi vagy szakterületi repozitóriumban. Különböző változatok léteznek arra vonatkozóan, hogy a tanulmány mely verzióját - benyújtott (preprint), elfogadott (postprint) vagy kiadói (publisher) -, mikor (a kiadói megjelenéskor vagy bizonyos idővel az után) és hová (szerzői honlap, intézményi vagy tematikus repozitórium, egyéb honlap) lehet feltölteni. A benyújtott (preprint) tanulmányok nyílt hozzáférhetőségének célja, hogy a szerzők mielőbb visszajelzést kapjanak a munkájukról. A postprint verzió esetében pedig az eredmények széles körű láthatóvá tétele a szándék.

A repozitóriumba kerülésnek azonban jellemzően nem feltétele a lektorálás, ezért állományában a szakmai tartalom szempontjából változó megbízhatóságú és színvonalú dokumentumok találhatók. Az elismert repozitóriumok (például REAL, SSRN, RePEc, arXiv) nagy előnye ugyanakkor, hogy egy adatbázisba gyüjtenek - az elfogadó folyóirat révén - bírálaton átesett, javított kéziratokat (is), ugyanis számos kiadó megengedi e változatok archiválását, amelyek így szabadon és széleskörüen hozzáférhetővé válnak. Ezek alapján a zöld közzététel valójában az arany változatot kiegészítő megoldásnak tekinthető. Suber [2012] hasonlóképpen amellett érvel, hogy az arany és a zöld közzététel egymást kiegészítő és egymást erősítő hatásúak, ugyanis mindegyiknek vannak előnyei a másikkal szemben: az arany változat lektorált írásokat közöl, pénzügyi szempontból önfenntartó vagy akár nyereséges is lehet, a zöld pedig (lehetséges) gyors állománybővüléssel szolgálhatja az olvasói igények kielégítését, egy intézmény teljes kutatási outputját magában foglalhatja, és biztosíthatja a dokumentumok megörzését is - következésképpen a nyílt hozzáférés arany és zöld változatának alkalmazása, támogatása egyaránt célszerü.

Egy más szemléletmód szerint (lásd például Rentier [2011]) azonban elsősorban nem a nyílt hozzáférésủ folyóiratokban való publikálást kell ösztönözni, hanem 
abban kell támogatni a szerzőket, hogy a megszokott módon publikáljanak, és emellett repozitóriumban tegyék hozzáférhetővé tanulmányukat. Fontos még felhívni a figyelmet arra is, hogy a repozitóriumok tartalmában és müködésében rejlö lehetőségek radikális újításokat hozhatnak a folyóiratok tevékenységét, így közlési formáit tekintve is. A kizárólag online megjelenésü Discrete Analysis címü matematikai folyóirat például nem tartalmaz egyetlen cikket sem, a lap által befogadott tanulmányok egy linken keresztül az arXivban érhetők el. A kéziratok benyújtása közvetlenül az arXivből történik a folyóirathoz, amely hagyományos módon lektorálja azokat. E publikálási megoldással sem a szerzők, sem az olvasók számára nem merülnek fel költségek, a lap pedig nagyon alacsonyan tarthatja müködési költségeit (Ball [2015]).

3. A hibrid közzététel modelljének többféle formája van. A nemzetközi tudományos szakfolyóiratokat is megjelentető, vezető profitorientált kiadók többsége napjainkban választási lehetőséget kínál szerzői számára: a szerzők eljárási díj megfizetése ellenében szabadon hozzáférhetővé tehetik cikküket, vagy nem fizetnek ilyen díjat, és tanulmányuk csak a folyóiratot, illetve a folyóiratot tartalmazó adatbázist előfizetők számára válik elérhetővé. Ilyen esetben a nyilt hozzáférés tehát csak azokra a cikkekre érvényes, amelyek esetében a szerző, illetve foglalkoztató intézménye vagy a kutatását finanszírozó szervezet kifizeti az eljárási díjat. A kiadók bevétele így részben a folyóiratok előfizetéséből, részben a szerzők által cikkeik nyílttá tételéért fizetett dijakból származik.

Ez az üzleti modell a szerző, pontosabban a mögötte álló intézmény szempontjából kérdéses lehet. Ha ugyanis előfizetője a cikket megjelentető szakfolyóiratnak, akkor gyakorlatilag kétszer fizet a kiadónak a megjelenő cikkért: egyrészt a folyóirat előfizetési díját, másrészt pedig a cikk nyílt hozzáférésének eljárási díját. Továbbgondolva a kétszeri fizetést, belátható, hogy mivel az előfizetés nem egy, hanem rendszerint több száz vagy több ezer folyóiratra vonatkozik, sok ezer cikk hozzáférésével az adott cikk előfizetése majdnem ingyen van. Az előfizetéssel nem rendelkező olvasók számára ugyanakkor az egyes cikkek viszonylag magas egységáron érhetők el, ${ }^{1}$ ha nem szabad hozzáférésüek. Mivel a hibrid modell révén is bővül a nyílt hozzáférésü cikkek száma és aránya, az előfizető részéröl felmerülhet a kérdés, hogy miért is fizet valójában, illetve miért nem kevesebbet, mint korábban, a nyílt hozzáférés elterjedését megelözően. ${ }^{2}$ A válasz többnyire az, hogy az előfizetések általában hozzáférést biztosítanak a folyóiratok előző években, évtizedekben megjelent számaihoz is.

A nyílt hozzáférés hibrid modelljének egy másik formája az, amikor egy folyóirat újonnan megjelenő számában közölt cikkek bizonyos ideig csak az előfizetők számára

\footnotetext{
${ }^{1}$ Az informatikai megoldások fejlődésével és a kiadók szolgáltatási stratégiájának kutatói igényekhez való igazodásával egy adott cikk hozzáférésére ma már többféle lehetőség van. Aki nem fizet elö, egy meghatározott, viszonylag rövid időtartamra (például 48 órára) „kibérelheti” a cikket. Ebben az esetben jellemzően csak olvasható a cikk - a hozzáférés díja ekkor a legalacsonyabb. A másik, a magasabb egységárú hozzáférés esetében a cikk felhőalapú rendszerben korlátlan ideig olvasható. További lehetőség - ami a legdrágább -, hogy a cikk megvásárolható pdf-formátumban mindazokkal a felhasználási lehetőségekkel (mentés, nyomtatás, olvasás), amelyek az előfizetéses e-folyóirat-adatbázisokban többnyire rendelkezésre állnak - az élvonalbeli kiadóknál 30-40 dollárért vagy euróért.

${ }^{2}$ A tartalomszolgáltató cégek és az élvonalbeli kiadók e-folyóirat-adatbázisainak előfizetési díja jellemzően nem csökken a nyílt hozzáférés terjedésével.
} 
hozzáférhetők, később azonban - jellemzően néhány hónap, de legfeljebb 24 hónap múlva - mindenki részére szabadon elérhetővé válnak - ez a késleltetett nyílt hozzáférés. Hazai példaként a Közgazdasági Szemle említhetö. Ebben az esetben az olvasói kör oldaláról az előfizetés a kutatási eredmények mielőbbi hozzáférése érdekében történik. A hibrid hozzáférés további változata az online nyílt hozzáférés: a folyóirat online kiadású számai - a legfrissebbeket is beleértve - szabadon hozzáférhetők mindenki számára, a nyomtatott formátuma viszont csak az előfizetők részére (ilyen például a Magyar Tudomány). A retrospektív nyílt hozzáférés esetében a korábbi, csak nyomtatott formában létező írások digitalizálásával vagy a régebbi cikkekre vonatkozó korlátozott, illetve fizetés ellenében történő hozzáférés feloldásával biztosítják a tartalom szélesebb körü elérhetőségét.

A kutatókra nehezedő publikálási kényszert kihasználó, nem etikusan működő és szakmai irányelveket nélkülözö ragadozó folyóiratok (predatory journals) is jellemzően nyílt hozzáférésűek. Müködésük meghatározója, hogy gyakran hamis tudománymetriai adatokat feltüntetve, minőségi, elismert szaklapnak adják ki magukat, miközben publikációs díj ellenében lektorálás nélkül vagy látszólagos lektorálási tevékenység alapján fogadják be és jelentetik meg online a beérkező kéziratokat. (Így valójában a szerzőoldali finanszírozású arany modellbe tartoznak.) A ragadozó folyóiratok száma dinamikusan növekszik. Ez jelentősen hozzájárul ahhoz, hogy a megbízható szakmai háttérrel rendelkező, nyílt hozzáférésủ folyóiratokat - különösen a viszonylag újakat és a nem élvonalbeli kiadók gondozásában megjelenőket - nehéz megkülönböztetni a parazita folyóiratoktól, amelyek általában szintén viszonylag fiatal, néhány éve müködő lapok. Ebből következően számos kutató esik a ragadozó folyóiratok csapdájába (többek közt a „call for papers” vagy más megtévesztő tartalmú, így például a címzett korábbi publikációjára hivatkozó e-mailek révén), ezzel értéktelenné téve tanulmányát; minthogy a tudományos szféra elfogadhatatlannak tartja a ragadozó lapok tevékenységét, és értékelhetetlennek az általuk megjelentetett írásokat. Jeffrey Beall ragadozó kiadókat és folyóiratokat egybegyüjtő listája ugyan nem tekinthető hivatalosnak és teljes körünek (már csak a folyamatos bővülés miatt sem), tudományos körökben mégis elterjedt a szaklapok szakmai tisztaságának, megbízhatóságának ellenőrzésére (Beall [2016]).

A közgazdaság- és gazdálkodástudomány területén megjelenő élvonalbeli és színvonalas nemzetközi szakfolyóiratok többsége valamely (vezető) profitorientált kiadó (például Elsevier, Sage, Wiley, Springer) gondozásában jelenik meg. E kiadókat a hibrid modell alkalmazása jellemzi - a szerző eljárási díj megfizetésével teheti szabadon hozzáférhetővé cikkét az egyébként előfizetéses folyóiratban. Bár az arany üzleti modell viszonylag elterjedt a gazdasági témájú lapok körében, közülük rendkívül kevés a magas színvonalú, valamint az impaktfaktorral is rendelkező szakfolyóirat (különösen alacsonynak tekinthető ez az arány más tudományterületekkel összehasonlítva, lásd: Gumpenberger és szerzötársai [2013] és Gunasekaran-Arunachalam [2014]).

A közgazdász kutatók számára abból a szempontból is problémát jelent, hogy csak kevés elismert arany változatú folyóirat müködik eljárási díj alapján, hogy ma már a rangos pályázatok - amelyeken keresztül forrásokhoz juthatnak - többnyire 
megkövetelik a kutatási eredmények szabadon hozzáférhetővé tételét. Minthogy a színvonalas nemzetközi szakfolyóiratok többségénél a hibrid hozzáférésű modell elsőként leírt formáját alkalmazzák, amelyre viszont jellemzően nem használhatók fel a pályázati források, a közgazdász kutatók csak az arany verziójú folyóiratok szük köréből választhatnak, ${ }^{3}$ amennyiben kutatási eredményeiket rangos helyen szeretnék közzétenni (és nem könyv megjelentetését tüzik ki célul). Végül kiemeljük, hogy a nyílt hozzáférésű publikálás támogatói - a szakfolyóiratok körében jelenleg uralkodó előfizetéses rendszer helyett - a szerzőoldali finanszírozású, arany üzleti modellek terjedését szorgalmazzák. E törekvés azonban számos vitapontot felvet a cikk további része ezekkel foglalkozik.

\section{A szerzőoldali finanszírozást igénylő modellek kritikus pontjai és megoldási lehetőségei}

A szakkiadók által alkalmazott arany és hibrid üzleti modellek jelentős részében a szakfolyóiratokban befogadott kéziratok nyílt hozzáférésü cikként való megjelentetése szerzőoldali finanszírozást igényel. Az olvasók ugyanakkor ingyenesen juthatnak hozzá a cikkek teljes szövegéhez, vagyis a publikált tartalomhoz, az új kutatási eredményekhez. Így a szerzőoldali finanszírozást igénylö modellek alkalmazásával az olvasók számára a publikációkhoz való hozzáférhetőség ugyan erősödik, a szerzök számára viszont a közlés lehetősége zártabbá válik - különösen, minthogy egyes országok, intézmények kutatói nem vagy csak korlátozottan tudnak forrást szerezni az eljárási dij megfizetésére (Peterson és szerzőtársai [2013]).

A nyílt hozzáférésű publikálással a kiadók ügyfeleivé valójában a szerzők válnak, nem pedig az olvasók (Björk és szerzőtársai [2010]). A két érintett kör között azonban átfedés van. A kutatóknak többszörös szerepük van a rendszerben: amellett, hogy szakcikkek szerzői és olvasói, többen szerkesztöként és lektorként is dolgoznak a folyóiratoknak, s ezért a munkájukért díjazásban általában nem részesülnek - ezt többnyire azzal indokolják, hogy közalkalmazottként fizetést kapnak.

A kutatók száma és ezzel párhuzamosan a publikációk köre folyamatosan növekszik. Ioannidis és szerzőtársai [2014] vizsgálatának eredményei arra mutatnak rá, hogy a kutatóknak csak kis hányada publikál, még kevesebben rendszeresen, és nagyon alacsony azoknak a száma, akik minden évben képesek szakfolyóiratcikket megjelentetni. ${ }^{4}$ Mindez ugyanakkor azt is jelenti, hogy a nyílt hozzáférésü publikálás legnagyobb

\footnotetext{
${ }^{3}$ Fontos megjegyezni, hogy a természettudomány szinte minden területén számottevően nagyobb a magas színvonalat képviselö, nyílt hozzáférésű szaklapok száma, valamint az összes rangos szakfolyóiraton belüli aránya (Gumpenberger és szerzőtársai [2013], Gunasekaran-Arunachalam [2014]). Ebből következően a természettudósok számára a publikációs követelményeknek való megfelelés lényegesen könnyebb. A pályázatok kiírása során sajnos gyakran nem veszik figyelembe a tudományterületek közötti eltéréseket, illetve a tudományterületi sajátosságokat, így a publikálási követelmények kapcsán sem.

${ }^{4}$ Ioannidis és szerzőtársai [2014] a Scopus adatbázis adatállományát az 1996 és 2011 közötti intervallumban vizsgálja. Arra az eredményre jut, hogy az ezen időszakban megjelent szakcikkek szerzőinek kevesebb mint egy százaléka volt képes minden évben szakcikket publikálni; e kutatók ugyanakkor az összes szakcikk több mint negyven százalékában müködtek közre szerzőként.
} 
részét a szorgalmas és értékes munkát végző kutatókkal, illetve intézményeikkel vagy az őket finanszírozó szervezetekkel fizettetnék vagy fizettetik meg. (Ennek hátterében az az indok állhat, hogy valójában a szerzők érdeke, hogy mások olvassák és hasznosítani tudják eredményeiket - a kapott hivatkozások száma pedig befolyásolja karrierútjukat.) Valójában azonban nemcsak a rendszeresen publikáló kutatók olvassák a szakfolyóiratcikkeket - bár valószínűsíthetö, hogy egyénenként ők a legtöbbet -, hanem a közlésben kevésbé aktív kutatók, egyetemi és föiskolai oktatók is, akik számára elengedhetetlen a szakmai felkészültséghez szakirodalmi ismereteik folyamatos bővítése, az új eredmények nyomon követése, valamint a tananyag új ismeretekkel való frissítése. Emellett az egyetemi, föiskolai hallgatók mint leendő szakemberek is használják tanulmányaik során a nyílt hozzáférésü közleményeket, különösen, mivel nagy részük már a „digitális bennszülöttek” csoportjához tartozik.

Tudományterületenként eltérő, hogy mekkora az átfedés a szerzők és az olvasók között. Houghton [2002] a repozitóriumokban elhelyezett tanulmányok bizonytalan szakmai színvonalához és értékéhez kapcsolódóan megjegyzi, hogy ahol nagy az átfedés a szerzői és az olvasói kör között, mint például az elméleti fizikában, ott a kritikai értékelés erösen érvényesül az olvasás során. Ahol viszont az olvasóközönség szélesebb, mint a szerzők köre, és a tanulmányokban közölt eredmények potenciális felhasználási területe bővebb, ott nagyobb szükség lenne a nyílt hozzáférésü közlemények szakértői bírálatára.

A nyílt hozzáférésű publikációk az akadémiai szférán kívüli szervezetek és döntéshozók, valamint bármely ország polgárai számára szintén hozzáférhetők. Kérdés viszont, hogy az online ingyenesen elérhető tudás és ismeretanyag mennyiben képes hasznosulni. A tudományos jellegü szakcikkek mint információforrások ugyanis sokak számára közvetlenül nem hasznosíthatók, vagy esetlegesen feleslegesek, minthogy például a szaknyelv ismerete és háttértudás hiányában meg sem értik őket a kutatóknál kevésbé felkészült szakemberek és a nem szakmabeliek. Továbbá, amint arra Kóczy [2014] is rámutat: „a puszta elérhetőség önmagában nem érték” (18. o.). Az egy tudomány- vagy szakterületen megjelenő folyóiratok és közlemények nagy száma miatt ugyanis egy kutató nem képes mindegyiket áttekinteni, többnyire csak azokat olvassa, amelyek szorosan kötődnek a szakterületéhez, és számára magas vagy megfelelő minőséget képviselnek.

A továbbiakban a szerzőoldali finanszírozást igénylő nyílt hozzáférésü üzleti modellek néhány kritikus tényezőjére, összefüggésére és következményére mutatunk rá, és emellett megoldási lehetőségeket és pozitív példákat is ismertetünk.

\section{A tradicionális és a nyílt hozzáférésü publikációs modell viszonya}

A tudományos kommunikáció során a tartalomszolgáltatás meghatározó gazdasági szereplői a kiadók. A szakfolyóiratok piacán néhány nagy, profitorientált kiadó van jelen, közöttük erős a verseny, és egyenként akár több száz folyóiratot is megjelentetnek. Mellettük számos kis kiadó müködik, többnyire a piaci réseket kihasználva (Houghton [2002]). 
Shieber [2013] szerint az olvasók szemszögéből a különböző szakfolyóiratok egymás (nem tökéletes) kiegészítőinek tekinthetők. Alapvetően azért, mert mindegyik minőségi szakfolyóirat arra törekszik, hogy új eredményeket, hozzáadott értéket tartalmazó cikkeket közöljön - így tehát az újdonságot tartalmazó közlemények egy csoportját szolgáltatják -, egyfajta szakterületi monopolhelyzetet kialakítva. Ez utóbbit igazolja az is, hogy a kiadók az általuk megjelentetett cikkekre a hagyományos publikálás során általában kizárólagos jogokat szereznek (például copyright) - miközben ingyen jutnak hozzá a kutatási eredményekhez, illetve az azokat tartalmazó írásokhoz, amelyeket alacsony költségvonzattal járó, viszonylag csekély technikai tökéletesítés után valójában jelentős árréssel értékesítenek. A szerző rámutat arra, hogy ebből adódóan korlátozott a piaci verseny a szakfolyóiratok között, ez pedig nem teszi hatékonnyá a piacukat. Ennek egyik meghatározó jele a folyóiratok előfizetési díjaiban meglévő jelentős különbségek, főként ha a profitorientált és a nonprofit kiadók árait hasonlítjuk össze.

Fontos viszont megjegyezni, hogy az olvasói oldalt tekintve a folyóiratok bizonyos mértékig helyettesítő viszonyban állnak egymással, mert a kutatók olvasásra fordítható ideje korlátozott, így a szakterületükön megjelenő szakfolyóiratok, illetve a szakterületükhöz kapcsolódó cikkeket (is) közlö periodikák teljes körü és folyamatos áttekintését többnyire nem sikerül megvalósítaniuk. Következésképpen bizonyos szempontok - például színvonal, hozzáférhetőség, hasznosság - alapján történik a lapok közötti választás. Amennyiben valamelyik jellemzőben változás következik be, másik folyóiratra válthat a kutató; az e-folyóirat-adatbázisok, illetve azok funkciói hatékonyabbá tették a helyettesítést. Előfizetői szempontból pedig - minthogy rendszerint egy meghatározott pénzügyi keret fordítható folyóirat-előfizetésre - a folyóiratok ára és színvonala befolyásolja az előfizetésükről való döntést. A folyóiratok elöfizetését azonban jellemzően csomagban nyújtják, vagyis több száz vagy több ezer folyóirathoz határoznak meg előfizetési díjat, nem pedig egy laphoz. Ebből adódóan nem a folyóiratok, hanem a csomagok szintjén jelenik meg a verseny (Shieber [2013]). A folyóiratok csomagban való nyújtásának előnye a kiadó számára, hogy az alacsony olvasottságú lapokra is - amelyeket egyébként valószínüleg lemondanának az előfizető intézmények - fedezetet tud szerezni.

A hagyományos publikációs modell esetében a kiadók bevételét a folyóirat előfizetői biztosítják. Az előfizetők számának emelkedésével a kiadók bevétele növekszik. Ez az elöfizetéses rendszer olyan időszakban alakult ki és terjedt el, amikor a szakfolyóiratok megjelenése kizárólag nyomtatott formátumban történt (Houghton és szerzőtársai [2009]). A technológia fejlődésének és az internetnek köszönhetően azonban a tudományos publikációk közvetítésének formája módosult, illetve változatosabbá vált.

A Finch [2012] jelentés egyértelmúen rámutat arra, hogy az internet a tudományos szakfolyóiratok piacának müködését is eröteljesen befolyásolja és módosítja. Több elismert kiadó (például Wiley, Sage, Elsevier) például arany vagy hibrid megoldással reagált a nyílt hozzáférést ösztönzö törekvésekre, átalakította szakfolyóiratai üzleti modelljét, illetve új lapokat indított. Azáltal pedig, hogy a világháló csökkentette a szakfolyóiratok piacának belépési korlátját - elsősorban a belépési költségeket -, 
számos új kiadó kezdte meg müködését, többnyire valamely nyílt hozzáférésü megoldással (Baruch és szerzőtársai [2013]).

Az eljárási díjas és az előfizetéses piac jellemzői egészen mások. Az előbbi esetében a szerző a kiadó ügyfele, nem az olvasó. A szerző szempontjából azonban a folyóiratok egymás helyettesítői (Shieber [2013]). A szerző több folyóirat közül választhatja ki - azok profilját, minőségét, olvasottságát és követelményeit mérlegelve -, hogy melyikhez küldi el kéziratát, amely csak az egyikben jelenhet meg. A nyílt hozzáférésü folyóiratok így valójában a szerzőkért versenyeznek, ami a korábbiaknál hatékonyabbá teszi a folyóiratok piacát (uo.). Az árazás pedig egy-egy cikkre vonatkozik, és nem csomagra vagy egy folyóiratra.

Bernius és szerzőtársai [2009] szerint - szemben a hagyományos előfizetéses rendszerrel - a kiadó bevétele stabil az arany nyílt hozzáférésű folyóiratok esetében, ha az eljárási díjat és az évfolyamonként, illetve számonként megjelenő publikációk számát változatlanul tartja. Az eljárási díjas folyóiratok így mérsékelni tudják a bevételhez kötődő kockázatukat. A kockázat meghatározó része abból ered, hogy elegendő számú, a folyóirat szakmai profiljához és színvonalához megfelelően illeszkedő kézirat érkezik-e be a szerkesztőséghez. Amennyiben nem, akkor a kiadó dönthet úgy, hogy kevesebb cikket jelentet meg lapszámonként, illetve évfolyamonként - ez a bevétel mérséklődésével jár együtt, a folyóirat szakmai színvonala ugyanakkor fenntartható. Ha viszont a bevétel szintjének megtartása a fontosabb a kiadó számára, akkor a szerkesztőség csökkenti a megjelentethető tanulmányokkal szembeni követelményeket, ez azonban hosszú távon, de akár már középtávon is, a lap hírnevének, minősítésének és besorolásának romlásához vezet. Az arany rendszerre való átállás azonban az idézett szerzők érvelése alapján hasznos lehet azon folyóiratok számára, amelyek szerkesztőségéhez viszonylag sok tanulmány érkezik be, illetve viszonylag sok cikket publikálnak - az eljárási díj által ugyanis függetlenné tudják tenni magukat az elöfizetők számától.

Kevésbé kockáztatják bevételeiket azok a hibrid formát alkalmazó kiadók, amelyek elöfizetéses rendszerük mellett lehetővé teszik az egyes cikkek nyílt hozzáférését szerzőoldali eljárási díjért. Ha a nyílt hozzáférésü opcióra alacsony a kereslet, akkor az nem jelent közvetlen bevételkiesést a kiadó számára, továbbá megmaradnak az előfizetésekből származó bevételek. Ha viszont a szerzők relatíve magas keresletet támasztanak aziránt, hogy publikációjuk nyílt hozzáférésü legyen, és így a kiadó a publikációs díjakon keresztül az előfizetésekből származó bevétele felett többletet tud realizálni, akkor ez egyben azt is jelenti, hogy bizonyos cikkekhez kötődően két irányból - a szerzőktől és az olvasóktól is - származik bevétele (Suber [2012]). Nem feltétlenül tekinthetö azonban következetes üzletpolitikának az, ha ugyanazon kutatótól (vagy intézményétöl) kétszer is bevételhez jut a kiadó - tehát az eljárási díjat térítő szerző (vagy intézménye) egyben előfizetője is a lapnak. A nyílt hozzáférésü publikálás támogatói ezt a hibrid megoldást ezért többnyire nem is tartják megfelelőnek és hosszú távon fenntarthatónak.

A jelenlegi, vagyis a vegyes piaci helyzetben a szerzőkért folyó versenyben az eljárási díjas folyóiratok versenyhátrányban vannak, mivel az előfizetéses folyóiratokban való publikálás ingyenes. Az eljárási díjas folyóiratok piacán a tudományos 
társaságok kiadói jelentős előnyhöz juthatnak a profitorientált kiadókkal szemben, elsősorban azért, mert az előfizetéses rend szerrel szemben nem folyóiratcsomagban értékesítenek, kiadói szolgáltatásaik egy szakcikk megjelentetéséhez kapcsolódnak. Ezt a tudományos társaságok kiadói lényegesen hatékonyabban tudják megvalósítani, még akkor is, ha nem képesek olyan mérethozadékot elérni, mint a nagy profitorientált kiadók (Shieber [2013]).

A nyílt hozzáférésű megoldások bevételét és költségeit Houghton és szerzötársai [2009] részletesen tanulmányozza. Jelentésüket és az általuk levont következtetéseket azonban számos kritika érte (például Hall, M. [2010], Hall, S. [2010]), különösen amiatt, hogy feltételezést feltételezésre, becslést becslésre halmoznak. Hall, $S$. [2010] szerint erősen kétséges Houghton és szerzőtársai [2009] azon állítása, hogy az eljárási díjas rendszer esetében a bevételi szint kiszámíthatóbb, ahol a szerzők nem sokkal a tanulmányuk elfogadása után, illetve kevéssel írásuk megjelenése előtt fizetik ki a publikációs díjat, mint amikor az elöfizetéses rendszerben jó néhány hónappal a hozzáférés előtt kell befizetni az előfizetési díjat.

Nemcsak a szerzőktől származó publikációs díjak finanszírozzák a nyílt hozzáférésü folyóiratokat, hanem az intézményektől kapott támogatások is. A profitorientált kiadókra inkább az előbbi, a nonprofit jellegüekre pedig az utóbbi a jellemző. A támogatási modell a humán- és társadalomtudományok területén elterjedt. A támogató szervezet részéről gyakran szükséges, hogy előre biztosítsa juttatását a folyóirat számára; a támogatásnak több fajtája lehet, így lehet pénzügyi és technikai jellegü is. Mounier [2011] azonban felhívja a figyelmet arra, hogy tudományos és pénzügyi szempontból egyaránt kockázatos kizárólag támogatásokból finanszírozni egy nyílt hozzáférésü folyóiratot. Számos folyóirat ugyanakkor egyetemi részleg (kar, intézet) vagy szakmai, illetve tudományos társaság kiadványa - ilyen esetben többnyire az adott szervezet finanszírozza a lapot. Előbbi esetében gyakran „egyetemi lokalizmus" jelenik meg, amely többnyire kedvezőtlenül hat a megjelenő publikációk színvonalára. Nehéz megszerezni azonban a forrásokat, ha a szerzők körét szélesítik, nyitottabbá teszik a lapot, és nem az a szervezet finanszírozza teljes egészében, amely kiadja. A szerkesztőbizottság összetétele is befolyásolja, hogy üzleti értelemben mennyire keresett egy lap (uo.). Arra is számos példa van ma már, hogy erős pénzügyi alappal rendelkező finanszírozási ügynökségek (például Wellcome Trust) alapítanak új nyílt hozzáférésű folyóiratot (Friend [2011]).

A hagyományos és a nyílt hozzáférésủ publikációs modellek költségoldalával lényegesen kevesebbet foglalkoznak a szakirodalomban, mint a bevételivel. Nyilvánvalónak tünik Houghton és szerzőtársai [2009] azon megállapítása, hogy az egyes folyóiratok költségei különböznek annak alapján, hogy hány kéziratot nyújtanak be szerkesztőségükhöz, mekkora az elutasítási ráta, hány lapszámot jelentetnek meg évfolyamonként, mekkora a cikkek terjedelme, mi jellemzi a lektorálást; hogy a folyóiratot nyomtatott, elektronikus vagy mindkét formában megjelentetik-e, valamint hogy mi jellemzi a kiadás üzleti modelljét és a méretgazdaságosság fokát. Kiemelik, hogy az online hozzáférés szignifikánsan csökkentette a marginális költséget, elsősorban a nyomtatási és az elosztási költségek jelentős mérséklődéséből eredően. Továbbá elősegítette és ésszerủvé tette a folyóiratok csomagban való kínálatát. Lényeges még, 
hogy online hozzáférés esetében az olvasók számától függetlenek a költségek, ami szintén hozzájárul ahhoz, hogy a szerzőkkel kívánják megfizettetni a nyílt hozzáférésü publikálást. Suber [2012] is rámutat arra, hogy a nyílt hozzáférésü folyóiratok alacsonyabb költséggel müködtethetők, mint az előfizetésesek: az előbbiek esetében nincs szükség a digitális jogok megszerzésére és az elöfizetés megszervezésére, nem merülnek fel a licenchez kötődő jogdíjak, és mérsékelhetők a marketingráfordítások is. Hall, S. [2010] azt veti fel, hogy amíg az előfizetéses modell a telítődési szakaszban van, és a költségei ismertek, addig a nyílt hozzáférésü közzététel még nem képes fenntartani önmagát. Következésképpen összehasonlításuk lehetősége korlátozott.

\section{A szerzőoldali finanszírozású dijak}

A nyílt hozzáférésü folyóiratok szerzőoldali finanszírozásához szükséges eljárási díj nagysága szakterületenként, kiadónként eltérő, amelyet a folyóirat elismertsége, besorolása, valamint a szerkesztőség szakmai munkájának színvonala is befolyásol. Mayer [2013] úgy véli, hogy minél magasabb szintü szolgáltatást (lektorálás, kiadás, láthatóság) nyújt egy kiadó, annál magasabb az eljárási díj. Finch [2012] hasonlóképpen úgy találja, hogy egyes magas státusú folyóiratok, amelyeknél jelentős mértékủ az elutasítási ráta, lényegesen magasabb eljárási díjat határozhatnak meg, mint az adott szakterület átlagos eljárási díja. Jellemző továbbá, hogy az újonnan létrejövő arany változatú folyóiratok eljárási díja alacsonyabb, mint a hibrid modellt alkalmazóké, aminek okát azonban még fel kell tárni (LERU [2015]). Egy lehetséges indok, hogy így akarnak betörni a piacra, szerzőket találni. Bernius és szerzőtársai [2009] pedig arra hívja fel a figyelmet, hogy az arany modell elterjedése magában rejti az eljárási díj emelkedésének kockázatát. A szerzők úgy vélik, nem akadályozható meg, hogy a kiadók növeljék az eljárási díjat, mivel eddig az előfizetési díjakat is emelték.

Fontos kiemelnünk, hogy a folyóiratok esetében a benyújtási díj (submission fee) nem azonos az eljárási díjjal. A kiadó a folyóirat szerkesztőségéhez benyújtott kéziratra veti ki a benyújtási díjat - gyakran a kezelési vagy az adminisztratív költségek fedezésére. Természetesen abban az esetben sem térítik vissza az összeget, ha a beadott írásmüvet elutasítják. A nyílt hozzáférésű folyóiratok eljárási díja viszont a publikálásra elfogadott tanulmányokra vonatkozik. Az üzleti, a közgazdasági és a pénzügyi lapok körében elterjedt a benyújtási díj kivetése. A magas presztízsü, valamint az új, innovatívabb lapok bevételt generálnak vele. A benyújtási díjat inkább az előfizetéses lapok alkalmazzák - s nem a nyílt hozzáférésủek -, elsősorban azok, amelyek nonprofit kiadóként müködnek. A benyújtási díj általában 50-200 dollár, de ennél jóval magasabb is lehet, akár az 500 dollárt is elérheti (Mark Ware [2010]).

A Mark Ware [2010] felmérése azt vizsgálta, hogy a benyújtási díj miként befolyásolja a nyílt hozzáférésű folyóiratok bevételét és üzleti modelljének müködését. A kiadók egyetértenek abban, hogy a benyújtási díjat is tartalmazó üzleti modell előnyt jelentene a nyílt hozzáférésü folyóiratok számára, különösen akkor, ha az elutasítások aránya magas. A felmérésből kiderült továbbá, hogy a benyújtási díjat sokkal inkább az előfizetéses folyóiratok fontolgatják, mint a nyílt hozzáférésüek. Teszik ezt annak érdekében, 
hogy pótlólagos bevételt tudjanak generálni akkor, ha a könyvtárak büdzséje csökken, és ennek következtében kevesebb folyóiratot tudnak előfizetni. A hátránya ugyanakkor ennek az üzleti modellnek az, hogy az a folyóirat, amely benyújtási díjat (is) alkalmaz, veszíthet a szerzői köréből, vagyis kevesebb kéziratot kaphat, és így a versenytársai előnybe kerülhetnek. Ha azonban a modell széleskörüen elterjed, akkor eltünik a relatív hátrány. A szerzők számára pedig a benyújtási díj olyan, mintha többletköltség lenne. Friend [2011] fontosnak tartja, hogy a fizetési procedúra elkülönüljön a minőség kontrolljának folyamatától, hogy szerzői oldalról a publikálásról való döntést ne a finanszírozás formája vagy a forrásszerzés nehézsége befolyásolja.

Az eljárási dij és a benyújtási díj együttes alkalmazásának többféle formája létezik. A benyújtási díj alkalmazása abból a szempontból előnyös a magas elutasítási rátával müködő szakfolyóiratok esetében, hogy a költségek fedezete egyenletesebbé válhat, ettől azonban még nem lesz jobb az üzleti modell. A benyújtási díj a folyóiratok számára bevételnövelö és kockázatcsökkentő tényezö, minthogy minden benyújtott kéziratra kiszabják. Magas elutasítási ráta esetén hatása jelentősebb, ilyenkor az eljárási díj akár jelentősen csökkenthetö is. Ennek a kombinált szerzőoldali finanszírozású modellnek az elönye az, hogy a bevétel sokkal kevésbé érzékeny az elutasítási ráta alakulására, illetve változására, mint a csak eljárási díjat magában foglaló megoldás (uo.).

A nyílt hozzáférésü publikálás jelenlegi gyakorlata, valamint a szakirodalomban és széles körben elterjedt elképzelések alapján az eljárási díj kifizetéséhez a szerzőnek kell gondoskodnia a forrásszerzésről. Felmerül azonban a kérdés, hogy a kutatási eredmények közzétételére szánt közpénzek miért nem közvetlenül a kiadókhoz, illetve a folyóiratokhoz folynak be. Ezáltal egyrészt a szerző mentesülne a forrásbiztosítástól, és jobban koncentrálhatna szakmai tevékenységére. Másrészt, a rendszer egészét tekintve, csökkenthetők lennének a tranzakciós költségek, nem lenne szükség minden egyes cikk esetében arra, hogy a finanszírozótól a kiadóig, illetve a folyóiratig eljusson a forrás - a szerző mint közvetítő pedig kiiktatható lenne. Harmadrészt, ha a nyílt hozzáférésü publikálás végső célját - a kutatási eredmények mindenki számára történő díjmentes hozzáférhetőségét -, valamint társadalmi hasznát tekintjük, akkor a vázolt támogatási út hatékonyabban juttathatná el a kutatási eredményeket az olvasókhoz, mivel a publikálási rendszerből nem szorulnának ki a forrással nem rendelkező, de jelentős eredményeket elért kutatók.

\section{Nem finanszírozott kutatások és a nyillt hozzáférés}

A publikációk szabadon hozzáférhetővé tétele mögött az a meghatározó indíték áll, hogy a közpénzböl finanszírozott kutatások eredményeinek ismerete mindenkit megillet. Abban az esetben, amikor egy tudományos kutatást, valamint annak eredményeit ismertető írásmü megjelenését a közszféra egy intézménye közvetlenül finanszírozza, racionálisnak, elfogadhatónak és etikusnak tekinthető a szerzőoldali eljárási díj kifizetésével kapcsolatos pénzmozgás. Fontos azonban felhívni a figyelmet arra, hogy számos olyan (magas színvonalú) kutatás valósul meg és tanulmány készül el - különösen a humán- és társadalomtudományok területén -, amelyek nem 
finanszírozottak, illetve amelyek esetében a kutató (vagy befogadó intézménye) csak közvetve részesedik a közfinanszírozásból, és azt közvetlenül viszont nem vagy nem feltétlenül tudja felhasználni eredményeinek publikálására. Ezt azért lényeges hangsúlyozni, mert a nyílt hozzáférés támogatói valójában azt feltételezik, hogy a szerzők, valamint az őket befogadó egyetemek, kutatóintézetek képesek finanszírozni az eljárási díjas nyílt hozzáférésü publikálást.

Azok a kutatók, akiknek a kutatásait nem finanszírozzák, tehát vizsgálódásaikat elsődlegesen vagy kizárólag kutatási témájuk iránti elkötelezettségük ösztönzi - ami egyébként a kutatói habitushoz nélkülözhetetlen -, rendkívül nehéz helyzetbe kerülhetnek a szerzőoldali eljárási díj alkalmazásakor. Különösen, ha figyelembe vesszük azt, hogy a humán- és társadalomtudományok területén a közlemények a mai napig tradicionálisan többnyire egy- vagy kétszerzősök. A legtöbb kutató nem engedheti meg magának a publikálás díjának „,saját zsebből” fizetését. Továbbá nem is etikus a tudományszervezés részéről a kutatók ilyen helyzetbe való kényszerítése. A folyóiratok által alkalmazott eljárási díj nagysága 500 és 5500 dollár vagy euró között mozog, vagyis megfizethetetlenül magas egy önálló kutató számára, hogy szabadon hozzáférhetővé tegye a cikkét, illetve hogy folyamatos publikálási tevékenysége során ekkora összeget fordítson egyegy tanulmánya megjelentetésére (lásd például Baruch és szerzőtársai [2013]). A publikációs díj kiszabása a kutatók számára akkor is megkérdőjelezhető, ha havi rendszeres vagy éves jövedelmüket közalkalmazottként az állam finanszírozza, azaz vitatható Janet Finchnek - a Finch-bizottság vezetőjének - azon álláspontja (említi Rushby [2013] 179. o.), hogy a kutatóknak valamely nyílt hozzáférésü formában kellene publikálniuk minden munkájukat, mivel őket is közpénzböl foglalkoztatják.

Peterson és szerzőtársai [2013] szerint a nyílt hozzáférés mellett érvelőknek nem szabad azt feltételezniük, hogy minden potenciális szerzőnek van forrása az arany modellbeli eljárási díj megfizetéséhez. Ezzel ugyanis egész egyszerủen számos ígéretes kutatót kizárnak az igényes tudományos publikálásból. Az eljárási díjas publikálás azért sem tekinthető korrektnek, mert mint ahogy azt Rizor-Holley [2014] is kiemeli, a humán- és társadalomtudományok területén dolgozó kutatók számára viszonylag ritkán nyújtanak forrást publikálási célra. A szerzőoldali finanszírozású modellek alkalmazása - kutatói, illetve szerzői oldalról nézve - elfogadható bizonyos tudományterületeken és helyzetekben, de nem megfelelő minden folyóirat esetében az egyes területeken eltérő kutatási, publikálási és finanszírozási szokások és lehetőségek miatt (Mounier [2011]).

Összegezve az eddig elmondottakat: a tradicionális publikálási rendszerben, ahol a folyóiratokban való közlés a szerzők számára ingyenes, bármely kutató valójában bármely lapban publikálhat; a kutatási eredmények és az azok alapján megírt tanulmány határozza meg a megjelentethetőséget. ${ }^{5}$ Ez azt jelenti, hogy kizárólag a kutatók szellemi teljesítménye számít a publikálásban: az új és releváns kutatási eredmények és a belőlük színvonalasan megírt tanulmány elégséges egy minőségi szakfolyóiratban való publikáláshoz. A szerzőoldali finanszírozást igénylő nyílt hozzáférésủ lapokban való megjelenéshez viszont pénzügyi forrás szükséges, nem elégséges tehát a kutatási produktum - aki forráshoz jut, annak van csak lehetősége eredményeit közzétenni. Ez

\footnotetext{
${ }^{5}$ Pontosabban azt, hogy milyen besorolású és profilú lap fogad(hat)ja be az írásmüvet.
} 
a kutatók számára nem azonos feltételeket teremt. Mindezekből következően nagyon veszélyes lehet a szerzőoldali finanszírozású nyílt hozzáférésü publikálás kiterjesztése, illetve elterjedése, különösen azokon a tudományterületeken, ahol viszonylag csekély mértékủ a kutatások és a publikálás finanszírozása.

$\mathrm{Az}$ egyenlőtlenségeket az is fokozná a nyílt hozzáférés arany modelljének széles körü alkalmazása során, hogy az élvonalbeli, magas impaktfaktorú és magas színvonalú szakfolyóiratok többnyire amerikai vagy nyugat-európai székhellyel müködnek, illetve rangos, a nemzetközi élvonalba tartozó szakkiadók gondozásában jelennek meg. Következésképpen nagy valószínűséggel magas eljárási díjat alkalmaznának, ahogy ez a hibrid nyílt hozzáférésủ megoldásnál is megfigyelhető. Ezen lapokban való (rendszeres) publikálást így a kevésbé tehetős szerzők (vagy intézményeik) nem engedhetnék meg maguknak.

A szerzők eljárási díjhoz való viszonyulásának egy más oldalát emeli ki McCabeSnyder [2014]: a szerzők eljárási díjas nyilt hozzáférésü publikálás iránti keresletének rugalmassága attól függ, hogy a hozzáférés nyílttá tétele által mennyire tudják az olvasottságot és a hivatkozások számát fokozni. A szerzőpáros úgy véli továbbá, hogy ha a nyílt hozzáférés valóban olyan jelentős mértékben növelné a hivatkozások számát, mint ahogy azt kezdetben feltételezték, akkor a szerzők kereslete valószínüleg viszonylag rugalmatlan lenne. Ha azonban a nyílt hozzáféréssel kevéssé lehet növelni a citációs előnyt, akkor az vagy nem fenntartható, vagy társadalmilag nem hatékony.

Egyes kiadók és a folyóiratokat gondozó tudományos társaságok részéről indultak olyan kezdeményezések, amelyek - felismerve a szerzőoldali finanszírozás terhét a nyílt hozzáférésủ publikálás során mérséklik az eljárási díj nagyságát, esetlegesen el is törlik, ha bizonyos, a szerzőkkel szemben támasztott feltételek teljesülnek. A kifinomultabb árukapcsolás sokkal inkább a természettudományok területén jellemző. Ennek hátterében valószínüleg az áll, hogy a nyílt hozzáférésü publikálás itt elterjedtebb - az élvonalbeli folyóiratok körében is -, mint a humán- és társadalomtudományok területén, ahol a nívós lapok esetében még mindig többnyire a hibrid nyílt hozzáférés a meghatározó.

A közgazdaság-tudományi folyóiratok körében is található már pozitív példa nyílt hozzáférésüre. Az Econometric Society által (a Wiley and Sons kiadónál) megjelentetett három lap közül kettő (Theoretical Economics, Quantitative Economics) ilyen. A társaság sem benyújtási díjat, sem eljárási díjat nem vet ki a tanulmányokra, viszont csak olyan cikkeket jelentet meg - lektorálást követöen -, amelyeknek legalább egy szerzője tagja az Econometric Societynak. Az éves tagdíj 2017-re 200 dollár, három évre (2017-2019) 475 dollár (http://www.econometricsociety.org/user/register); így nagyságrendileg is alacsonyabb egy (potenciális) szerző befektetése a nyílt hozzáférésbe, emellett a tagsággal számos további előny és kedvezmény jár.

A hibrid modell alapján müködő folyóiratok között van arra pozitív példa, hogy kedvezményt biztosítanak az eljárási díjból azon szerzőknek, akiknek intézményei előfizetik a lapot. Az American Chemical Society (ACS) például engedményt ad az eljárási díjból cikkük szabadon hozzáférhetővé tétele esetén azon szerzőknek, akiknek intézményei online előfizetői a társaság összes publikációinak. Az engedmény mértéke attól is függ, hogy a szerzö tagja-e a társaságnak, valamint hogy a nyílt hozzáférést azonnal 
igényli vagy csak 12 hónappal a megjelenést követően (http://pubs.acs.org). A különböző kedvezmények alapján csökkentett eljárási díj mértéke a legtöbb esetben még mindig olyan nagyságrendü - legalább 1000 dollár vagy euró, de ennek többszöröse is lehet -, hogy rendkívül nagy terhet jelent a szerzö(k) számára egy nem finanszírozott kutatás esetében. Így a humán- és társadalomtudományok területén célszerübb megoldás lehet az, hogy a tudományos társaságok tagdijain keresztül történik a cikkek szabadon hozzáférhetővé tétele, illetve a nyílt hozzáférésủ folyóiratok finanszírozása.

Tekintsünk erre egy példát! Tegyük fel, hogy egy tudományos társaság megtéríti tagjai számára az eljárási díjat, amennyiben egy bizonyos - a társaság profiljához illeszkedő - szakfolyóiratban publikálnak, amelyet egy profitorientált kiadó jelentet meg. Feltételezzük, hogy a folyóiratnak évente négy száma jelenik meg, mindegyik hat cikket tartalmaz; ez azt jelenti, hogy évi 24 cikket közöl a lap. Amennyiben a Schimmer és szerzőtársai [2015] által kalkulált 2000 eurós átlagos eljárási díjjal számolunk, akkor a tudományos társaság a 24 cikk esetében összesen legfeljebb 48000 eurót fordít eljárási díjra éves szinten. Ez azt jelenti, hogy a fedezeti pont 100 eurós éves tagdíjnál 480 tag, 200 eurós éves tagdíjnál 240 tag, 300 eurós éves tagdíjnál pedig 160 tag. (Azon egyszerüsítő feltételezés esetén, hogy a tagdíjbevételt teljesen egészében a publikálás finanszírozására fordítják.) Tekintve azonban, hogy a folyóiratban nem csak tagok publikálhatnak - minthogy az nem a társaság lapja, a világ bármely részén dolgozó kutatók írhatnak bele -, valószínúleg a társaságnak nem kell minden cikk eljárási díját finanszíroznia. Továbbá lehetséges, hogy ha a kiadóval a társaság szervezetközi megállapodást köt, akkor az eljárási díj nagysága akár 1500 vagy 1000 euróra is mérséklödhet; következésképpen maximum évi 36 000, illetve 24000 euróra csökkenhet a nyílt hozzáférésü publikálás finanszírozása.

Amennyiben a tudományos társaságok tagjaik nyílt hozzáférésű publikálását a fent leírt módon támogatnák, akkor mind több kutató ismerné fel, hogy megéri és elönyös a tudományos társaságokhoz csatlakozni - az eljárási díj nagyságánál lényegesen alacsonyabb tagdíjat kellene csak fizetniük, így akár több társaságnak is a tagjaivá válhatnának; a társasági tagságnak pedig számos más előnyét is élvezhetnék. Ha pedig növekszik egy társaság tagjainak a száma, akkor a tagdíjból származó növekvő bevételek eredményeképpen további folyóirat vagy folyóiratok esetében vállalhatja a társaság az eljárási díj térítését.

\section{A nyílt hozzáférésü publikálás intézményi szintü finanszírozásáról}

A tudományos eredmények szakmailag elismert, eljárási díj alapján működő nyílt hozzáférésü folyóiratban való publikálásának szükséges feltétele a szerzői oldal részéröl rendelkezésre álló pénzügyi forrás. E tekintetben nemcsak közvetlenül a szerzői szintü kérdésekkel fontos foglalkozni, hanem a kutatókat, illetve szerzőket foglalkoztató kutatóintézetek, felsőoktatási intézmények érintettségével és választási lehetőségeivel is. A szerzők ugyanis mint egyének nem tehetők ki a publikálási díj alapján nyílt hozzáférést biztosító üzleti modelleknek: a befogadó szervezetek felelősséggel tartoznak a kutatóik által elért eredmények - szakmailag megfelelő helyen való - publikálásának 
biztosításáért. A nyílt hozzáférésű publikálás kapcsán Mayer [2013] fel is hívja a figyelmet arra, hogy - a kutatási alapok mellett - a kutatót foglalkoztató intézmény kötelezettsége, hogy fedezze a szerzőoldali publikálási költségeket.

A kutatóintézeteknek és a felsőoktatási intézményeknek többnyire korlátozottak a publikálásra fordítható pénzügyi forrásaik. Ezért a vezetésük számára komoly döntést jelenthet a nyílt hozzáférésü publikálás finanszírozásához kapcsolódóan, hogy mely kutatók írásainak, illetve mely kutatási eredményeknek a megjelenését támogassa, valamint hogy hány közlemény megjelenéséhez biztosítson forrást. Továbbá rendkívül eltérő, hogy a befogadó szervezetek mekkora összegből gazdálkodhatnak a publikálás támogatása során. Így a szerzőoldali finanszírozáson alapuló nyílt hozzáférésű publikálás lehetőségeit alapvetően meghatározza az intézmény pénzügyi helyzete. Mounier [2011] hangsúlyozza, hogy ebben a rendszerben megint csak azok a kutatók jutnak előnyhöz, akik jó pénzügyi helyzetben lévő intézményben dolgoznak. Ugyanakkor pedig a szerzőoldali finanszírozású, nyílt hozzáférésủ modell pénzügyi nyomás alatt tartja a kutatókat foglalkoztató szervezeteket.

Már számos kutatóintézet és felsőoktatási intézmény felismerte annak szükségességét, hogy a nyílt hozzáférésü publikálás megvalósulásához forrást kell biztosítania a szerzők részére. Eddig azonban csak viszonylag kevés helyen különítettek el forrásokat kifejezetten a szerzőoldali finanszírozású publikálás támogatására, illetve dolgoztak ki olyan eljárásmódot, amely ezen források felhasználását célozza (Friend [2011]).

2008-ban a Berkeley (University of California) az első intézmények egyike volt, amely a nyílt hozzáférésủ publikálás finanszírozásához pénzügyi támogatást kezdett nyújtani a kutatói számára (Teplitzky-Phillips [2016]). Hamarosan több élvonalbeli egyetem, így például az MIT (https://libraries.mit.edu/scholarly/publishing/oa-publishing-support/ open-access-publishing-fund) és a Cornell (https://www.library.cornell.edu/about/ collections/coap) is alapot különített el kutatóik nyílt hozzáférésü folyóiratokban való publikálásának - bizonyos feltételekhez kötött - finanszírozására.

Hazai példaként említendő a Szegedi Tudományegyetem (SZTE) 2015 őszén indult, nyílt hozzáférésü publikálást támogató projektje. Az első félév tapasztalatai alapján módosított, jelenleg érvényben lévő feltételek alapján az egyetem szerzői számára a nyílt hozzáférést támogató alap az eljárási díj 70 százalékát finanszírozza, a fennmaradó részt pedig a szerzőknek más forrásból kell fedezniük. A támogatás csak az arany közzétételt alkalmazó folyóiratokhoz vehető igénybe, hibrid lapokhoz nem. A támogatási kérelem elbírálásánál fontos szempont a folyóirat minősége. Lényeges továbbá, hogy a Szegedi Tudományegyetem nyílt hozzáférésủ tagsági szerződést kötött néhány élvonalbeli kiadóval, amely révén a szerzőknek alacsonyabb eljárási díjat kell fizetniük (http://szerzoknek.ek.szte.hu/tamogatott-oa-publikalas).

$\mathrm{Az}$ intézményi nyílt hozzáférésű tagság általában 15 százalékos kedvezményt biztosít az eljárási díjból a szerzők számára. Az egyetemek által a szerzőik számára nyújtott támogatás mindenképpen pozitív fejlemény. Továbbra is problémát jelent viszont az, hogy az egyetemi támogatási alapok jellemzően nem a teljes eljárási díjra biztosítanak fedezetet, így a szerzőknek más finanszírozási forrást is kell találniuk. Tényleges elörelépést az jelentene, ha az eljárási díj 100 százalékát fedeznék az egyetemi támogatási alapok. 
Egy másik sikeres megoldásra nyújt példát a CERN által szervezett és irányított társaság, a részecskefizika területén a nyílt hozzáférésủ publikálást szponzoráló konzorcium, a SCOAP ${ }^{3}$ (Sponsoring Consortium of Open Access Publishing in Particle Physics, https://scoap3.org/), amely a legnagyobb presztízsű részecskefizikai folyóiratok egy csoportját nyílt hozzáférésüvé alakította át (Schimmer és szerzőtársai [2015]). E folyóiratok számára a SCOAP ${ }^{3}$ fedezi az eljárási díjat, így a finanszírozási és az ehhez kapcsolódó adminisztratív terhek alól egyaránt mentesíti a szerzőket (https://scoap3.org/scoap3journals).

A fentiek alapján könnyen belátható Peterson és szerzőtársai [2013] azon megállapítása, hogy az arany üzleti modell bevezetésével és elterjedésével nem szünnek meg a kutatók, az intézmények és az országok közti különbségek. A szükös anyagi forrással rendelkezők nem vagy csak korlátozottan tudnak publikálni az eljárási díjat alkalmazó folyóiratokban - még akkor is, ha a szakmai teljesítményük, vagyis kutatási eredményeik és írásaik színvonala ezt lehetővé tenné. Erre tekintettel a kiadóknak és a tudományszervezés területén dolgozóknak alaposan meg kell fontolniuk a folyóiratok üzleti modelljeit, annak érdekében, hogy a vagyonegyenlőtlenségek ne vezessenek újabb egyenlőtlenségekhez a tudományos kommunikáció terén is.

\section{Az előfizetés és a nyilt hozzáférés viszonya intézményi szinten}

A hagyományos üzleti modellben a szakfolyóiratok előfizetéses formában érhetők el az olvasók számára; a lap kiadójának bevétele elsődlegesen ebből származik. A kutatóintézetek és felsőoktatási intézmények könyvtárai így előfizetés alapján biztosítják kutatóik számára a szakfolyóiratokat. Mint intézményi előfizetők - többnyire konzorciumi keretek között - jellemzően folyóiratcsomagra fizetnek elö, amelynek során a kiadó vagy az e-folyóirat-adatbázist nyújtó tartalomszolgáltató cég valamilyen szempontból korlátozza (például IP-tartomány) és felügyeli (például letöltésszám) a hozzáférést. Az ilyen, úgynevezett Big Deal esetében a kínálati oldal szereplöi által szabott feltételek és árak nagyon eltérhetnek egymástól. Houghton és szerzőtársai [2009] szerint konzorcium keretében rendszerint alacsonyabb elöfizetési díjakat lehet elérni, ugyanakkor viszont koordinációs és tárgyalási többletköltségek merülhetnek fel.

Az előfizetési díjak az elmúlt 10-15 évben tartósan és jelentősen növekedtek. Ennek ellenére a kereslet erősen rugalmatlan (Forgues-Liarte [2013]), ami elsősorban arra vezethető vissza, hogy a kutatómunkához, a szakterület fejlődésének nyomon követéséhez feltétlenül szükségesek a szakfolyóiratok. Az előfizetési díjak annak ellenére magasak, hogy az internet tudományos közlésben való szerepe növekedett, és jelentősen csökkentette a folyóiratok kiadási (nyomtatási) és disztribúciós költségeit (McCabe-Snyder [2014]).

A könyvtárak a tudásállomány bővítését egyre nehezebben tudják megvalósítani. Egyrészt azért, mert növekszik a folyóiratok, illetve az e-folyóirat-adatbázisok előfizetési díja - vagyis a szakirodalom elérése tekintetében a hozzáférési korlát emelkedik -, másrészt pedig, mert jellemzöen csökken a könyvtári büdzsé. Mindez sürgeti a nyílt hozzáférés megvalósulását (Mann és szerzötársai [2009], Eger és szerzőtársai [2015]). 
A kutatóintézetek és a felsőoktatási intézmények számára - egyes tudományterületeken - komoly pénzügyi terhet jelent a nyílt hozzáférésü publikálás támogatásának és a szakirodalom elérésének egyidejü finanszírozása. Ennek alapján Friend [2011] azt javasolja, hogy a könyvtárak folyóirat-előfizetésre fordított büdzséjét át kellene csoportosítani a nyílt hozzáférésű publikálás támogatására. Az Európai Kutatóegyetemek Ligája a kettős pénzügyi terhelés - vagyis a folyóiratokra való elöfizetés és a publikációs díjak egyidejű fizetésének - elkerülése érdekében támogatja az arany folyóiratmodellt (LERU [2015]). Kiemeli, hogy az érintettek összefogására van szükség - még nincsen köztük összehangolt együttmüködés, pedig ez szükséges a célok elérése érdekében. Elképzelhető azonban, hogy lesznek olyan tudományterületek, így például a közgazdaság-tudomány, amelyeken közép-, de akár hosszú távon is fennmarad a kétoldalú finanszírozás. Egyrészt, mert jelenleg rendkívül alacsony a rangos arany modellt követö, nyílt hozzáférésü folyóiratok száma és aránya. Másrészt, ha továbbra is csekély marad az e tudományterületeken folyó kutatások finanszírozottsága, akkor a potenciális szerzők többsége nem lesz képes fedezni az eljárási díjat. Ebben az esetben pedig a kutatót foglalkoztató intézményeknél az optimális forrásmegosztás dilemmája merül fel.

A kutatókat foglalkoztató intézmények pénzügyi helyzete és tudományos színvonala számottevően befolyásolja, hogy milyen arányban fordítanak folyóirat-adatbázisok előfizetésére és nyílt hozzáférésủ publikálásra. Mindez pedig jelentős hatást gyakorol a folyóiratok üzleti modelljeinek elterjedésére, fenntarthatóságára és a különböző nyílt hozzáférésű megoldások jövőjére. A nyílt hozzáférésű publikálás elgondolásának megvalósulása szempontjából adott intézmény számára az a racionális, valamint hosszú távon fenntartható megoldás, ha az elöfizetési díjak összegénél kevesebb kiadással jár a kutatók nyílt hozzáférésü publikálásának finanszírozása.

Ez azonban nem feltétlenül van így. Különösen, ha a kutatási eredményeket az intézmény vezetése bizonyos mértékig láthatóvá kívánja tenni. Azon intézményeknél, ahol folyamatos, intenzív és eredményes a kutatómunka, ugyanakkor a pénzügyi keretek szükösek, nagy valószínűséggel előfordulhat, hogy a kutatási eredmények közzététele érdekében nagyobb összeget kellene fordítani nyílt publikálásra, mint a folyóiratok előfizetésére. (Ezen intézményeket a nyílt hozzáférésü publikálásra való átállás, valamint a kettős finanszírozás különösen hátrányosan érinti.) Azok a (tartósan) kedvező pénzügyi helyzetben lévő intézmények, amelyek eddig is sokat költöttek folyóirat-elöfizetésre, valószínűleg a források átcsoportosításával a nyílt hozzáférésủ publikálást is tudják finanszírozni.

Érdemes még megjegyezni, hogy pénzügyi szempontból azok az intézmények járnak a legjobban, amelyeknek a publikálási aktivitása csekély - a folyóiratelöfizetésre fordított összeg egy része akár meg is takarítható a nyílt hozzáférésü rendszerek elterjedésével. A szakfolyóiratokban való rendszeres közlés azonban elengedhetetlen a kutatók részéről, mert enélkül hosszú, de akár már középtávon is mind saját maguk, mind intézményük szakmai elismertségét jelentősen ronthatják. A publikációkhoz való nyílt hozzáférés jelentős hasznot eredményezne azon intézményeknek, amelyek a számukra szükséges folyóiratoknak csak egy bizonyos körét képesek elöfizetni. 


\section{Néhány megállapítás a nyílt hozzáférésü publikálás rendszerszintű megközelítéséhez}

Olvasói oldalról tekintve a publikációk nyílt hozzáférésének előnyeivel és elterjedésének szükségességével kapcsolatban nagyrészt egyetértés van a szakemberek között. A felhasználókra gyakorolt közvetett, pozitív hatást is mindinkább hangsúlyozzák; a szélesebb körü tudásállományhoz való hozzáférés elősegíti a $\mathrm{K}+\mathrm{F}$-tevékenységek eredményes és hatékony megvalósulását (Björk és szerzőtársai [2010]), ugyanakkor pedig az induló vállalkozások számára is hasznos lehet, amelyek nem rendelkeznek saját kutatási kapacitással, és csak csekély összegü tőkét birtokolnak (Dekker [2014]). Arról viszont élénk szakmai vita zajlik, hogy mennyiben és miként valósuljon meg az áttérés a nyílt hozzáférésü publikálásra, és ennek finanszírozása hogyan történjen.

A három nyílt hozzáférésű üzleti modell eltérő súllyal van jelen a különböző tudományterületeken. Baruch és szerzőtársai [2013] szerint a szakfolyóiratok tudományés szakterületenként - a kutatások jellegéből, finanszírozottságuk hátteréből és mértékéből, valamint a publikálási szokásokban és követelményekben meglévő eltérésekből eredően - különbözö finanszírozási formát igényelnek. E tekintetben nagy az eltérés a társadalom- és a természettudomány között: szerzői oldalról a jelenlegi nyílt hozzáférés finanszírozási helyzete a természettudománynak kedvez. Továbbá az arany modellt kevésbé támogatja a kutatói közösség, mint a zöldet - elöbbi müködtetéséhez megfelelö üzleti modell kifejlesztésére van szükség, ez azonban viszonylag nehéznek tünik (Mounier [2011]).

Friend [2011] szerint még nem lehet tudni, hogy melyik rendszer és milyen üzleti modell marad meg hosszú távon. Ezzel kapcsolatban igen eltérnek a vélemények. Vannak, akik szerint az arany üzleti modell valójában fenntarthatatlan, mert a szerzők által befizetett publikációs díj sem előnyösebb, mint az intézményeik által fedezett előfizetési díj (Rizor-Holley [2014]). Más nézetek szerint a hosszú távú fenntarthatóság problémája sokkal inkább a zöld modellt érinti, mint az aranyat, mivel számos kutatási alap, hogy elkerülje a „dupla teherviselést”, kizárólag az arany verziót finanszírozza (Mayer [2013]).

A nyílt hozzáférésű publikálás pártfogói kiemelik, hogy e publikálási rendszerben közvetlen költségmegtakarítás érhető el (Björk és szerzőtársai [2010]). Ezzel ellentétes vélemény szerint viszont a rendszerköltségek akár emelkedhetnek is az arany rendszer elterjedésével - a kiadók árszabási politikájától függően (Bernius és szerzőtársai [2009]). Houghton és szerzőtársai [2009] a tudományos publikálás három alternatív modelljének - az előfizetéses és az eljárási díjas nyitott hozzáférésnek, valamint a saját publikáció archiválásának (amikor a szerzők írásukat nyílt hozzáférésü repozitóriumokba helyezik) - költségeit és hasznát vetette egybe. A vizsgálat megállapította, hogy egy e-formátumú cikkre jutó előállítási, publikálási és terjesztési költségek az előfizetéses esetben a legmagasabbak, és a saját archiválásnál a legalacsonyabbak. A felsőoktatás számára (makro- vagy rendszerszinten) a szakfolyóiratcikkek költségeiben jelentős megtakarítást jelenthet az elöfizetésesröl a nyílt hozzáférésre való átállás. A közvetlen költségeken túl a rendszerköltségeket is lehet csökkenteni. 
A nyílt hozzáférésü publikálás támogatása és finanszírozása terén a Max Planck Digital Library munkatársai úgy látják, hogy csak akkor bővülhet a nyílt hozzáférésü publikálás, ha a folyóiratok előfizetésére szánt keretek megnyílnak a nyílt publikálás eljárási díjainak a fedezésére (Schimmer és szerzőtársai [2015]). Amellett érvelnek, hogy a folyóiratok elöfizetésére szánt ráfordításokat a nyílt hozzáférésü publikálásra kell átcsoportosítani. Hangsúlyozzák, hogy az előfizetéses rendszerben az olvasói oldalról történő finanszírozásból származó kiadói bevétel elegendő mértékü a nyílt hozzáférésü publikálási rendszerre való átálláshoz és annak fenntartásához. Az e megállapításukat alátámasztó kalkulációban abból indulnak ki, hogy globálisan a szakfolyóiratok előfizetéséből származó éves bevétel megközelítően 7,6 milliárd euró, továbbá hogy az előfizetések alapján 2 millió szakfolyóiratcikk érhető el, ebből mintegy 1,5 millió a Web of Science által indexelt. Így a jelenlegi előfizetéses rendszerben a cikkenkénti költség 3800, illetve 5000 euró. A nyílt hozzáférésü publikálási rendszerben az eljárási díj mértéke széles tartományban mozog (500 és 5500 euró vagy dollár között), átlagos értéke azonban 2000 euró alatt van, vagyis jelentősen alatta marad a cikkenkénti előfizetés költségének. Mindez azt is jelenti, hogy az előfizetéses rendszerben rendelkezésre áll az a pénzösszeg, amely a folyóiratok teljes körének nyílt müködtetéséhez szükséges. (A nyílt publikálási rendszer fenntarthatóságát az is erősíti, hogy - amint arra a fentiekben már történt utalás a kiadók a nyílt hozzáférésű folyóiratokat alacsonyabb költséggel képesek müködtetni, mint az elöfizetéseseket, Suber [2012].)

Schimmer és szerzőtársai [2015] szerint az előfizetéses rendszerröl a nyílt hozzáférésüre való átállás pénzügyi kockázat nélkül megvalósítható. Ez a megállapítás azonban vitatható, ugyanis e számítások csak azt igazolják, hogy a nyílt hozzáférésű publikálási rendszerre van fedezet az előfizetésekből származó bevételek átcsoportosításával, de azt nem veszik figyelembe, hogy az elöfizetések és az eljárási díjak forráshelyei nem feltétlenül azonosak, valamint hogy az előfizetések forrásai - részben az előbbiek miatt - nem minden esetben csoportosíthatók át a nyílt hozzáférésű publikálás finanszírozására. Továbbá a forrással rendelkezők érdekeltsége sem feltétlenül azonos. Emiatt megint csak a természettudományok képviselői kerülnek relatív előnybe azáltal, hogy kutatásaikat többnyire nem - vagy nem közvetlenül - a foglalkoztató intézményük finanszírozza, és jut forrás az eljárási díjak megfizetésére.

A nyílt hozzáférés széles körü elterjedését nemcsak az üzleti modellek módosításának szükségessége korlátozza, hanem az is, hogy a kutatókat foglalkoztató intézmények, a kutatástámogató szervezetek és a szakkiadók többnyire egymástól eltérő szabályozást alkalmaznak (Holl [2016]). A nyílt hozzáférésű publikálás finanszírozásának több szempontú harmonizálása érdekében elengedhetetlen a benne részt vevők kooperációja. Erre utal valójában Schimmer és szerzőtársai [2015] megállapítása is: az előfizetéses rendszerről a nyílt rendszerre való átállás csak globálisan valósítható meg, a világ legkiválóbb kutatóintézeteinek az együttmüködésével. Lényeges továbbá a hosszú távú siker szempontjából az érintettek pénzügyi haszna mellett a nem pénzügyi hasznok számításba vétele is (Friend [2011]). 


\section{Összegzés}

E tanulmány a nyílt hozzáférésủ publikálás finanszírozási kérdéseit helyezte a középpontba. Elsősorban azt vizsgálta, hogy miként érinti a kutatókat mint szerzőket a szakfolyóiratok nyílt hozzáférésü üzleti modellek szerinti, szerzőoldali finanszírozása.

A nyílt hozzáférésű publikálás támogatói a három fő modell közül az arany verziót szorgalmazzák, amely - különösen a minőségi lapok esetében - a szerzők részéről megköveteli a megjelenés költségeihez való hozzájárulást. Az eljárási díj nagysága folyóiratonként eltérő, a lektorok által elfogadott tanulmányra vetik ki, s nem azonos a benyújtási díjjal, amely a benyújtott kéziratokra vonatkozik.

Azok a kutatók, akiknek a kutatásait nem finanszírozzák, rendkívül nehéz helyzetbe kerülhetnek az arany üzleti modell, pontosabban a folyóiratok azon gyakorlatának terjedésével, hogy szerzőoldali eljárási dijat alkalmaznak. Pénzügyi forrás tehát szükséges a közléshez, nem elegendő a kutatási eredmény és az értékes írásmű, mint a hagyományos publikálási rendszerben. Egyes kiadók és a szakfolyóiratokat gondozó tudományos társaságok azonban már nyújtanak megoldásokat az eljárási díj mérséklésére, elengedésére bizonyos feltételek teljesülése esetén.

A kutatókat foglalkoztató intézményeknek támogatniuk kell a nyílt hozzáférésü publikálást - erre ma már hazai példa (SZTE) is van. Az intézmények pénzügyi helyzetétől is függ azonban, hogy erre milyen lehetőségek nyílnak. A folyóiratok előfizetése és a nyílt publikálás támogatása egyidejüleg hosszú távon nem tartható fenn. A nyílt hozzáférésü publikálás mellett érvelők szerint a források átcsoportosítására van szükség - az előfizetési díjakat eljárási díjakra kellene fordítani. A széles körü megvalósítás és a finanszírozás módjáról élénk szakmai vita folyik; a nézetkülönbséget az is számottevően fokozza, hogy az egyes tudományterületeken eltérö a kutatások támogatásának mértéke, a nyílt hozzáférésű folyóiratok száma, aránya és színvonala, valamint a tudományos közlés jellege is. A számítások alapján az elöfizetéses rendszerben rendelkezésre áll az a pénzösszeg, amely a folyóiratok teljes körének nyílttá tételéhez szükséges lenne. Fontos azonban ehhez hozzátenni, hogy a reallokáció nem minden esetben valósítható meg, ugyanis az előfizetések és az eljárási díjak forráshelyei sok esetben nem azonosak.

\section{Hivatkozások}

BALL, P. [2015]: The Journal That Publishes No Papers: Mathematics Journal 'Overlays' arXiv Preprint Server. Nature, Vol. 526. 146. o. http://dx.doi.org/10.1038/nature.2015.18351.

Baruch, Y.-Ghobadian, A.-Özbilgin, M. [2013]: Editorial: Open Access - the Wrong Response to a Complex Question: The Case of the Finch Report. British Journal of Management, Vol. 24. No. 2. 147-155. o. http://dx.doi.org/10.1111/1467-8551.12016.

Beall, J. [2016]: List of publishers. Beall's List: Potential, Possible, or Probable Predatory Scholarly Open-Access Publishers. Scholarly Open Access: Critical Analysis of Scholarly Open-access Publishing. https://scholarlyoa.com/publishers. 
Bernius, S.-Hanauske, M.-König, W.-Dugall, B. [2009]: Open Access Models and their Implications for the Players on the Scientific Publishing Market. Economic Analysis \& Policy, Vol. 39. No. 1. 103-115. o. http://dx.doi.org/10.1016/s0313-5926(09)50046-x.

BJörk, B.-C.-Welling, P.-LaAkso, M.-Majlender, P.-Hedlund, T.-GuĐnason, G. [2010]: Open Access to the Scientific Journal Literature: Situation 2009. PLoS ONE, Vol. 5. No. 6. e11273. o. http://dx.doi.org/10.1371/journal.pone.0011273.

BOAI [2002]: Budapest Open Access Initiative. Az eredeti BOAI deklaráció, Budapest, február 14. http://www.budapestopenaccessinitiative.org/read.

Dekker, S. [2014]: Going for Gold. Information Services and Use, Vol. 34. No. 3-4. 185-188. o.

Eger, T.-Scheufen, M.-Meierrieks, D. [2015]: The Determinants of Open Access Publishing: Survey Evidence from Germany. European Journal of Law and Economics, Vol. 39. No. 3. 475-503. o. http://dx.doi.org/10.1007/s10657-015-9488-x.

FINCH, J. [2012]: Accessibility, Sustainability, Excellence: How to Expand Access to Research Publications. Report of the Working Group on Expanding Access to Published Research Findings. Research Information Network, https://www.acu.ac.uk/research-informationnetwork/finch-report-final.

Forgues, B.-Liarte, S. [2013]: Academic Publishing: Past and Future. M@n@gement, Vol. 16. No. 5. 739-756. o.

Friend, F. [2011]: Open Access Business Models for Research Funders and Universities. Knowledge Exchange Briefing Paper, Knowledge Exchange, szeptember 20. http://publish openaccess.blogspot.hu/2011/09/briefing-paper-on-open-access-business.html.

Gumpenberger, C.-Ovalle-Perandones, M.-A.-Gorraiz, J. [2013]: On the Impact of Gold Open Access Journals. Scientometrics, Vol. 96. No. 1. 221-238. o. http://dx.doi.org/10.1007/ s11192-012-0902-7.

Gunasekaran, S.-Arunachalam, S. [2014]: The Impact Factors of Open Access and Subscription Journals Across Fields. Current Science, Vol. 107. No. 3. 380-388. o.

Hall, M. [2010]: Response: Minerva's Owl. A Response to John Houghton and Charles Oppenheim's ‘The Economic Implications of Alternative Publishing Models'. Prometheus, Vol. 28. No. 1. 61-71. o. http://dx.doi.org/10.1080/08109021003676375.

Hall, S. [2010]: Response: A Commentary on 'The Economic Implications of Alternative Publishing Models'. Prometheus, Vol. 28. No. 1. 73-84. o. http://dx.doi.org/10.1080/ 08109021003676383.

Holl András [2016]: Tudományos kommunikáció a XXI. században - Open Science. Magyar Tudomány, Vol. 117. No. 3. 307-316. o.

Houghton, J. [2002]: The Crisis in Scholarly Communication: An Economic Analysis. Kézirat, http://www.vala.org.au/vala2002/2002pdf/16Houton.pdf.

Houghton, J.-Rasmussen, B.-Sheehan, P.-Oppenheim, C.-Morris, A.-Creaser, C.Greenwood, H.-Summers, M.-Gourlay, A. [2009]: Economic Implications of Alternative Scholarly Publishing Models: Exploring the Costs and Benefits. A Report to the Joint Information Systems Committee. Victoria University, Loughborough University.

IoAnnidis, J. P. A.-Boyack, K. W.-Klavans, R. [2014]: Estimates of the Continuously Publishing Core in the Scientific Workforce. PLoS ONE, Vol. 9. No. 7. e101698. http://dx.doi. org/10.1371/journal.pone.0101698.

Kóczy Á. LÁszló [2014]: A publikálás folyamata és az Open Access dilemmái a közgazdaság-tudományban. Könyv és Nevelés, Vol. 16. No. 1. 8-20. o. http://folyoiratok.ofi.hu/ konyv-es-neveles/a-publikalas-folyamata-es-az-open-acces-dilemmai-a-kozgazdasagtudomanyban. 
LERU [2015]: "Christmas is over. Research Funding Should Go to Research, not to Publishers!” Moving Forwards on Open Access, LERU Statement for the 2016 Dutch EU Presidency. League of European Research Universities, Leuven, http://www.leru.org/files/general/ LERU\%20Statement\%20Moving\%20Forwards\%20on\%20Open\%20Access\%282\%29.pdf.

Mann, F.-von Walter, B.-Hess, T.-Wigand, R. T. [2009]: Open Access Publishing in Science. Communications of the ACM, Vol. 52. No. 3. 135-139. o. http://dx.doi. org/10.1145/1467247.1467279.

Mark Ware [2010]: Submission Fees - A Tool in the Transition to Open Access? Knowledge Exchange. Mark Ware Consulting Ltd, http://www.markwareconsulting.com/wordpress/wpcontent/uploads/2010/12/KE_Submission_fees_Short_Report_2010-11-25-1.pdf.

Mayer, K. U. [2013]: Open Access Improves Returns to Public Research Funding: A Perspective from Germany. Information Services and Use, Vol. 33. No. 1. 3-10. o.

McCabe, M. J.-SNyder, C. M. [2014]: Identifying the Effect of Open Access on Citations Using a Panel of Science Journals. Economic Inquiry, Vol. 52. No. 4. 1284-1300. o. http:// dx.doi.org/10.1111/ecin.12064.

Mounier, P. [2011]: Freemium as a Sustainable Economic Model for Open Access Electronic Publishing in Humanities and Social Sciences. Information Services and Use, Vol. 31. No. 3-4. 225-233. o.

OECD [1997]: National Innovation Systems. OECD, Párizs, http://www.oecd.org/science/ inno/2101733.pdf.

Peterson, A. T.-Emmett, A.-Greenberg, M. L. [2013]: Open Access and the Author-Pays Problem: Assuring Access for Readers and Authors in the Global Academic Community of Scholars. Journal of Librarianship and Scholarly Communication, Vol. 1. No. 3. eP1064. o. http://dx.doi.org/10.7710/2162-3309.1064.

Rentier, B. [2011]: The OA Interviews: Bernard Rentier, Rector of the University of Liège. http://www.richardpoynder.co.uk/Rentier_Interview.pdf.

Rizor, S. L.-Holley, R. P. [2014]: Open Access Goals Revisited: How Green and Gold Open Access Are Meeting (or not) Their Original Goals. Journal of Scholarly Publishing, Vol. 45. No. 4. 321-335. o. https://doi.org/10.3138/jsp.45.4.01.

Rushby, N. [2013]: Editorial: Open Access. British Journal of Educational Technology, Vol. 44. No. 2. 179-182. o. http://dx.doi.org/10.1111/bjet.12027.

Schimmer, R.-Geschunn, K. K.-Vogler, A. [2015]: Disrupting the Subscription Journals' Business Model for the Necessary Large-scale Transformation to Open Access. A Max Planck Digital Library Open Access Policy White Paper, http://dx.doi.org/10.17617/1.3.

Shieber, S. [2013]: Why Open Access is Better for Scholarly Societies. The Occasional Pamphlet on Scholarly Communication. Január 29. https://blogs.harvard.edu/pamphlet/2013/01/29/ why-open-access-is-better-for-scholarly-societies.

Suber, P. [2012]: Open Access. [e-book] MIT Press, Cambridge, MA.

Teplitzky, S.-Phillips, M. [2016]: Evaluating the Impact of Open Access at Berkeley: Results from the 2015 Survey of Berkeley Research Impact Initiative (BRII) Funding Recipients. College and Research Libraries, Vol. 77. No. 5. 568-581. o. https://doi.org/10.5860/crl.77.5.568. 